\title{
CONTAINER TERMINAL OPERATIONS TRANSFORMATION
}

\author{
Andina Azka ${ }^{1}$, Aandarwati ${ }^{2}$, David P Sirait ${ }^{3}$,
}

1. STMT Trisakti, 2. STMT Trisakti, 3. STMT Trisakti

Corresponding author: andinaadzka@gmail.com

\begin{abstract}
Container terminal operation is one of the important things to support the activities in port. But there are many problems in container terminal operation, such as lack of information, traffic, truck, waiting time, berthing window, inaccessibility of operator, slow terminal performance, etc. All these problems can give significant impacts for the business in many ways and the major impacts are high cost, improper services, and the main problem is losing customer. The purpose of this research is studying about container terminal operation's transformation as modern services at terminal operation 3 port of Tanjung Priok. Researchers retrieved the data with the direct field observation and intending to observe how the transformation of container terminal operation without system or traditional into container terminal using modern and service-oriented system. Transformation was resulting a benefit for container terminal operations such as reliable service time, clear roles, PIC and real instructions, and increase productivity. With the qualitative analysis, researcher can describe this object.

Keyword: transformation, terminal container, modern, service and system
\end{abstract}

\section{Introduction}

Indonesia is a maritime country. The sea port is important for the country's economy, as it plays the vital role of the maritime economy's activities. The ability of port to ensure efficient cargo transfers is one of the main dimension of the overall port function as a transport medium (Rafi, n.d.). With the rapid expansion of trans-oceanic trading and logistic, the port must be professional, reliable, and modern for handling containers and cargo that comes and goes out of the port. The improvement is important for the sustainability and reliability of a port, as also become more efficient for further development.

Indonesia Port Corporation II (IPC) is one of the State-Owned Enterprises (SOE) in the maritime industry engaged in port and logistic services that implements outsourcing to support performance and productivity. Making innovation for service is a must for the organization because technology system can increase the competitiveness in business (Noorani, 2014). Causes of Problem Factors: 1a. Manpower (discipline), 1 b. Manpower (cooperation), 1c. Manpower (job positioning), 1d. Manpower (number of TKBM), 1e. Manpower (competence), 2a. Facility (standardized 
port), 2b. Facilities (dock capacity). 2c. Facilities (back up area), 3a. Machines (readiness tool), 3b. Machines (completeness of supporting tools), 3c. Machines (number of tools), 4a. Materials (timeliness), 4b. Materials (number of fleets), 4c. Materials (load capacity), 4d. Materials (fleet conditions) according to (Badarusman \& Trisakti, n.d.)

The IPC's directorate of operations manages three core portfolios, such as marine services, container terminal, and non-container terminal. As the topic related to container terminal operations is to enhance the operation from traditional into modern and service-oriented, the IPC needs the transformation to achieve its goal.

The reasons of container terminal operation's transformation are:

- Unclear vessel progress status

- No fix berthing window

- Long truck waiting time

- Inaccurate stowage affecting vessel stability

- Lack of information

- Unsterile terminal

- Unclear/No EIR received

- Traffic jam

- Unclear Service time at the gate

- Damage container

- Operator not ready

- Inaccurate data from the container yard

- $\mathrm{S} / \mathrm{L}$ do the planning and operations

- Slow terminal performance

Those issues above impact IPC's business in many possibilities such as the loss of cost, reliability issues, service issues, and losing customers.

The benefits of transformation are to:

- Reliable service time

- Clear roles, PIC and instructions

- Increase of productivity 
- System standardization

The transformation's objective is to bring terminals into integration level when all terminals connect each other. The phases of this transformation are:

- Set up minimum infrastructure and terminal environment as basis for survival kit, such as cleaning yard, marking yard and fix traffic flow. Those applied along the implementation of educational standardization

- Set up minimum process and build awareness, such as paper based documents, PC and office-application and basic gate activity.

- Establish Sustainability through end-to-end improvement, such as fix layout, prepare standard organization and people.

- Optimize process through system, such as systemized control tower, use handheld, VMT, pager, and terminal operation system.

- Data Integration Terminal to Terminal and Centralize the P\&C.

Nowadays using system for supporting terminal operation is very important and these research was discussed about the important to use technology system in container terminal operation for current and future business (HAEFNER \& BIESCHKE, 1998) and (Liu et al., 2002 ) and et al. (M. kia, E. Shayan and F. Ghotb , 2000). TOS (Terminal Operation System) is composed of sub-systems for administration, planning, scheduling, executing and reporting parts. The administration part supports the management of container move orders from shipping lines. Generally, container move orders are transferred to the terminal through electronic data interchange (EDI) or internet access. This information is basic input data for the planning part(Kim \& Lee, 2015). TOS is intended to make operation more transparent for all stakeholders and it is the core of the entire transformation operations. TOS that used by the IPC operation terminal 3 is OPUS.

"OPUS Terminal Planning System" allows multiple users to be involved in the planning process by sharing the same part of the data base and it consists of the following three modules. "Berth Planning" covers the 
long-term schedule, the dedicate berth management, liner's private voyage number management, and berth chart. "Vessel Planning "provides a flexible planning tool for extraordinary circumstances, managing container handling orders, twin/tandem planning, dual cycling operation, multi user planning, evaluating ship plans, checking vessel stability, and handling late cargo arrivals after cargo closing time. "Yard Planning" estimates the workload in the yard soon, allocates yard space based on gate-in pattern, and changes stacking rules in accordance with current yard utilization ratio.

The transformation is an integration between resources, infrastructure and system. According to the previous study (Cavalieri, Ouertani, Zhibin, \& Rondini, 2017), Port of Tanjung Priok made service transformation from manual to modern service. IPC's manpower and equipment also need assessment. The company must have an educational training program to improve the quality of the human resources to suit the needs and desires of the company. This educational training program is provided for prospective new workers as well as old workers with the aim to improve the quality of human resources owned by the company (Lasse \& Darunanto, n.d.).

Operations training are designed to provide support to operational team and give knowledge and skill for the success of transformation. Operations trainings are required to be the right "change management" tools to utilize the TOS, standardize the knowledge with world class quality and also as the enable or tools for operational team to identify talent. And these issues about container terminal had been explained before $(\mathrm{Li}, \mathrm{Wu}, \& \mathrm{Goh}$, 2015).

\section{Method}

Researchers use descriptive qualitative analysis method for this paper using secondary data obtained from IPC. Qualitative research is a type of scientific research. Researchers retrieved the data with the direct field observation and intending to observe the transformation of container terminal operation without system or traditional into container terminal using modern and service-oriented system. 


\section{Discussion and Result}

Based on the analysis of the data obtained the transformation is proven to be successful in Operation Terminal 3 Port of TanjungPriok as the data shown below:

Phase 1 is expected to finish within 2013-2015.

- Set up minimum infrastructure and terminal environment as basis for survival kit, such as cleaning yard, marking yard and fix traffic flow. Those applied along the implementation of educational standardization (kejarpaket C) for 6 weeks.

- Set up minimum process and build awareness, such as paper based documents, PC and office-application and basic gate activity. Those applied along the implementation of survival kit for 6 weeks.

- Establish Sustainability through end-to-end improvement, such as fix layout, prepare standard organization and people. Those applied along the implementation of standardization for 3 months.

Phase 2 is expected to finish within 2015-2017

- Optimize process through system, such as systemized control tower, use handheld, VMT, pager, and terminal operation system. Those applied along the implementation of standardization for 3 months.

\section{Phase 1 and 2 transformation timelines}

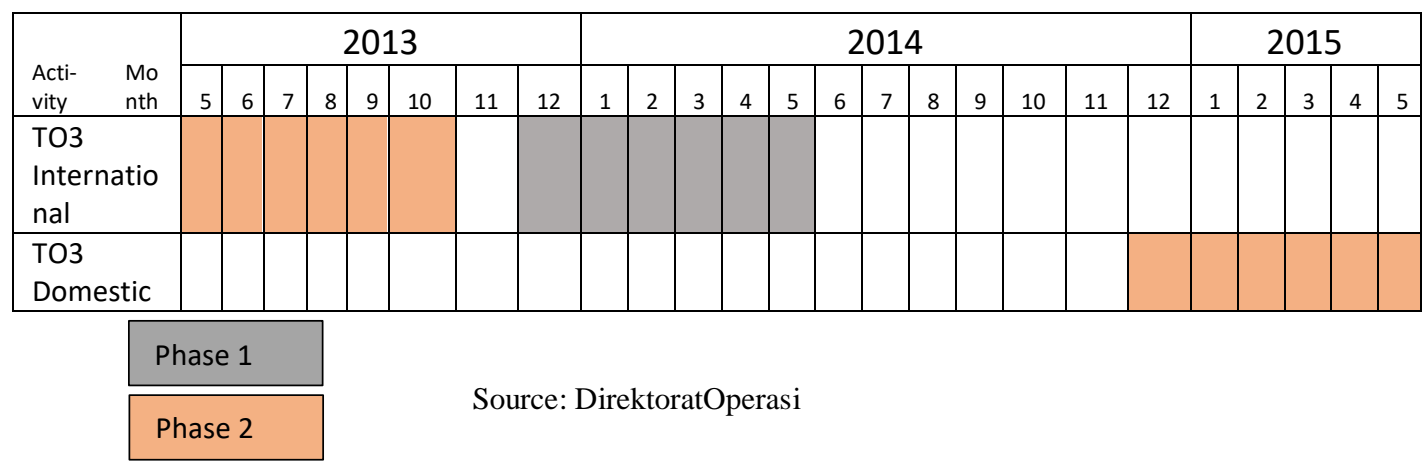

Phase 1 has been accomplished in 6 months. TO3 Int'1 from May 2013 up to October 2013 while TO3 Dom from Aug 2014 up to February 2015. 
Phase 2 has been accomplished in $\sim 8$ months. TO3 Int'l from November 2013 up to May 2014.

This is the result from this research explained comparative 'before and after' about transformation in port of Tanjung Priok. There two phases in this transformation.

Transformation on Safety in TO2, TO3 Domestic and Intl Phase 1: Paket-C, Survival Kit and Standardization

\begin{tabular}{|c|c|c|}
\hline Comparison & Before & After \\
\hline Billing location & $\begin{array}{l}\text { Billing Office is scattered } \\
\text { per terminal operation }\end{array}$ & $\begin{array}{l}\text { All customer directly do payment in the } \\
\text { centralized billing site } \\
\text { Self-service and EDC payment is } \\
\text { provided to assist customer in doing } \\
\text { payment }\end{array}$ \\
\hline Billing Process & $\begin{array}{l}\text { Payment system using BPRP } \\
\text { causing lots of Account } \\
\text { Receivable }\end{array}$ & $\begin{array}{l}\text { Improved User Interface by } \\
\text { implementing New Billing System in } \\
\text { Priok Port } \\
\text { Virtual Private Network (VPN) for Top } \\
4 \text { biggest customer for self-entry } \\
\text { payment }\end{array}$ \\
\hline Container Yard & $\begin{array}{l}\text { No marking causing } \\
\text { container stacking unclear }\end{array}$ & $\begin{array}{l}\text { Already marked to give clear direction } \\
\text { and stacking position } \\
\text { Traffic flow is regulated by using white } \\
\text { marking on the yard }\end{array}$ \\
\hline Equipment & $\begin{array}{l}\text { No Equipment ID in RTGC } \\
\text { and CY }\end{array}$ & $\begin{array}{l}\text { All RTGC in container yard already has } \\
\text { an ID for e.g. RTG-10-TSJ } \\
\text { Every container yard is named } \\
\text { systematically and marked by block } \\
\text { sign }\end{array}$ \\
\hline Yard process & $\begin{array}{l}\text { OVD container is not } \\
\text { separated and not yet one } \\
\text { door direction } \\
\text { Crane for coal stevedoring is } \\
\text { located under RTGC } \\
\text { Yard operation is mixed with } \\
\text { non-container cargo }\end{array}$ & $\begin{array}{l}\text { One door direction and grouped } \\
\text { according type of container } \\
\text { Re-layouting container yard to separate } \\
\text { non-container and container operation } \\
\text { Yard operation works smoothly after } \\
\text { removing non-related equipment } \\
\text { Operator assistant uses handheld to } \\
\text { input container data }\end{array}$ \\
\hline
\end{tabular}

\section{Transformation on Control Tower for TO3 Intl}

Phase 2: Systemization

\begin{tabular}{|l|l|l|}
\hline Comparison & Before & After \\
\hline \multirow{5}{*}{ Control Tower } & $\begin{array}{l}\text { No centralized control tower } \\
\text { and no sufficient planning \& } \\
\text { control activities }\end{array}$ & $\begin{array}{l}\text { Set up centralized control tower in } \\
\text { technical building } \\
\text { New and modern computers are } \\
\text { procured to provide reliable } \\
\text { performance }\end{array}$ \\
\hline
\end{tabular}




\begin{tabular}{|l|l|l|}
\hline $\begin{array}{l}\text { Planning } \\
\text { Control }\end{array}$ & $\begin{array}{l}\text { Set up planning \& control organization } \\
\text { structure } \\
\text { Manpower fulfillment in already } \\
\text { approved organization structure }\end{array}$ \\
\hline IT Infrastructure & $\begin{array}{l}\text { Already available IT } \\
\text { infrastructure but no TOS } \\
\text { implemented to support } \\
\text { container operation }\end{array}$ & $\begin{array}{l}\text { Serminal area to assist controlling } \\
\text { activity } \\
\text { Construction of Wi-Fi tower to support } \\
\text { data transaction between CY and CT }\end{array}$ \\
\hline $\begin{array}{l}\text { TOS } \\
\text { implementation }\end{array}$ & $\begin{array}{l}\text { Shiphing activities after OPUS } \\
\text { implementation } \\
\text { Yard planning activities after OPUS } \\
\text { implementation }\end{array}$ \\
\hline
\end{tabular}

\section{Conclusion}

This paper has studied about container terminal operation transformation from the state without system/traditional to modern service with usage of technology system. There are many problems in terminal operations which can be solved by the system. And this system makes operations more transparent for all stakeholders. With TOS will optimize the activities in terminal operation. Wherein all activities in terminal operation are controlled by people with this system. The result shows the phases to migrate the terminal operation 3 from manual to modern system. The phases of this transformation are set up minimum infrastructure and terminal environment, optimize process by system, build awareness for safety, establish sustainability and data Integration Terminal to Terminal and Centralize the $\mathrm{P} \& \mathrm{C}$.

Those phases are targeted for people, process, technology, equipment, infrastructure and facilities assessment. Transformation was resulting a benefit for container terminal operations such as reliable service time, clear roles, PIC and real instructions, and increase productivity. Due to the changes in demand of the world trade especially through sea transportation, the port should not be satisfied with the changes that have been done, there will always come the need of upgrading the service quality of the port to follow the changes. 


\section{References}

Badarusman, B., \& Trisakti, S. (N.D.). Hambatan Bongkar Muat Scrap Waktu Sandar Kapal Di Dermaga Terminal, 327-333.

Cavalieri, S., Ouertani, Z. M., Zhibin, J., \& Rondini, A. (2017). Service Transformation In Industrial Companies. International Journal of Production Research, 7543(November), 1-4. Https://Doi.Org/10.1080/00207543.2017.1378830

HAEFNER, L. E., \& BIESCHKE, M. S. (1998). ITS Opportunities In Port Operations. Transportation Conference Proceedings, 131-134.

Kim, K. H., \& Lee, H. (2015). Container Terminal Operation : Current Trends And Future Challenges. Https://Doi.Org/10.1007/978-3-31911891-8

Lasse, D., \& Darunanto, D. (N.D.). Bagi Anak Buah Kapal, 257-266.

Li, W., Wu, Y., \& Goh, M. (2015). Planning And Scheduling For Maritime Container Yards: Supporting And Facilitating The Global Supply Network. Planning And Scheduling For Maritime Container Yards: Supporting And Facilitating The Global Supply Network, (Stromberg 2015), 1-110. Https://Doi.Org/10.1007/978-3-319-17025-1

Liu, C. I., Jula, H., \& Ioannou, P. A. (2002). Design, Simulation, And Evaluation Of Automated Container Terminals. IEEE Transactions On Intelligent Transportation Systems, 3(1), 12-26. Https://Doi.Org/10.1109/6979.994792

Noorani, I. (2014). Service Innovation And Competitive Advantage. European Journal Of Business And Innovation Research, 2(1), 12-38. Retrieved From Http://Www.Eajournals.Org/WpContent/Uploads/Service-Innovation-And-Competitive-Advantage.Pdf Rafi, S. (n.d.). Dwelling time management, 220-228.

The importance of information technology in port terminal operations. (2000), 30(3), 331-344.

www.wikipedia.org (accessed November 10, 2017) 